\title{
Trace Elements in Almandine Garnet, Vemireddipalle Area, Krishna District, Andhra Pradesh, India
}

\author{
Nazia Sultana
}

Research Scholar, Department of Geology, Acharya Nagarjuna University, Nagarjuna Nagar, Guntur, Andhra Pradesh, India

\section{ABSTRACT}

Almandine is an iron-aluminium garnet and the deep red transparent stones are often called precious garnet and are used as gemstones. The aim of the research is to study the trace element concentrations. ICP-MS is used to analyze the trace elements. The study found that $\mathrm{Y}, \mathrm{Zn}, \mathrm{Sc}, \mathrm{Cr}, \mathrm{V}, \mathrm{Zr}$ and Co are present comparatively in higher concentrations.

Keywords :Trace Elements, Almandine Garnet, ICP-MS

\section{INTRODUCTION}

A trace element is a chemical element whose concentration is in trace amounts. In geochemistry, a trace element is one whose concentration is less than $1000 \mathrm{ppm}$ or $0.1 \%$ of a rock's composition. The term is used mainly in igneous petrology. Trace elements will be compatible with either a liquid or solid phase. If compatible with a mineral, it will be incorporated into a solid phase (e.g., nickel's compatibility with olivine). If it is incompatible with any existing mineral phase it will remain in the liquid magma phase (https://en.wikipedia. org/wiki/Trace_element).

The name Almandine is a corruption of Alabanda, a region in Asia Minor, where these stones were cut in ancient times. Chemically, almandine is an ironaluminium garnet and the deep red transparent stones are often called precious garnet and are used as gemstones (https://en.wikipedia.org/wiki/Garnet). It occurs in metamorphic rocks, especially mica schists, amphibolites, and granulites; granites, aplites, and granitic pegmatites (https://www.britannica. com/science/garnet). This variety is amongst the most valued garnet gems (https://www.wikigem pedia.com/garnet.html).

The aim of the research is to study the trace element concentrations in Almandine Garnet gemstone from Vemireddipalle area, Krishna District, Andhra Pradesh, India.

\section{METHODS AND MATERIAL}

ICP-MS (Inductively coupled plasma mass spectrometry) is used to analyze trace elements, i.e., $\mathrm{Ba}, \mathrm{Ga}, \mathrm{Sc}, \mathrm{V}, \mathrm{Th}, \mathrm{Pb}, \mathrm{Ni}, \mathrm{Co}, \mathrm{Rb}, \mathrm{Sr}, \mathrm{Y}, \mathrm{Zr}, \mathrm{Nb}, \mathrm{Cr}, \mathrm{Cu}$, $\mathrm{Zn}, \mathrm{Ge}, \mathrm{As}, \mathrm{Sn}, \mathrm{La}, \mathrm{Ce}, \mathrm{Pr}, \mathrm{Nd}, \mathrm{Eu}, \mathrm{Sm}, \mathrm{Tb}, \mathrm{Gd}, \mathrm{Dy}$, Ho, Er, Tm, Yb, Lu, Hf, Ta, U, Li, and Cs. The concentrations of these elements with reference to individual samples is observed. The Laser ablation technique is adopted in the present study.

\section{RESULTS AND DISCUSSION}

In this section, a detail of Trace elements are presented. The concentrations of various elements (in ppm) are given in table 1 . 
Out of the total number of elements, estimated only Y, Zn, Sc, Cr, V, Zr and Co are comparatively present in higher concentrations (Table 1).

TABLE 1. TRACE ELEMENTS CONCENTRATIONS (PPM OR MG/KG)

\begin{tabular}{|c|c|c|c|c|}
\hline $\begin{array}{c}\text { Trace } \\
\text { Elements }\end{array}$ & 1 & 2 & 3 & 4 \\
\hline $\mathrm{Ba}$ & $<50$ & $<50$ & $<50$ & $<50$ \\
\hline $\mathrm{Ga}$ & 5 & $<5$ & $<5$ & $<5$ \\
\hline $\mathrm{Sc}$ & 77 & 103 & 145 & 127 \\
\hline $\mathrm{V}$ & 56 & 26 & 38 & 44 \\
\hline $\mathrm{Th}$ & 9 & 13 & 11 & 12 \\
\hline $\mathrm{Pb}$ & 6 & 11 & 9 & 12 \\
\hline $\mathrm{Ni}$ & 2 & $<2$ & 11 & 7 \\
\hline Co & 14 & 7 & 45 & 34 \\
\hline $\mathrm{Rb}$ & 5 & 6 & 8 & 8 \\
\hline $\mathrm{Sr}$ & $<5$ & $<5$ & $<5$ & $<5$ \\
\hline $\mathrm{Y}$ & 174 & 369 & 49 & 86 \\
\hline $\mathrm{Zr}$ & 26 & 19 & 39 & 29 \\
\hline $\mathrm{Nb}$ & $<5$ & $<5$ & $<5$ & $<5$ \\
\hline $\mathrm{Cr}$ & 34 & 86 & 37 & 81 \\
\hline $\mathrm{Cu}$ & 8 & 9 & 8 & 8 \\
\hline $\mathrm{Zn}$ & 132 & 168 & 175 & 145 \\
\hline $\mathrm{Ge}$ & 5.80 & 9.12 & 3.50 & 3.49 \\
\hline As & $<5$ & $<5$ & $<5$ & $<5$ \\
\hline Sn & $<5$ & $<5$ & $<5$ & $<5$ \\
\hline $\mathrm{La}$ & 2.43 & 1.05 & 1.75 & 1.25 \\
\hline $\mathrm{Ce}$ & 6.33 & 2.93 & 7.24 & 4.07 \\
\hline $\operatorname{Pr}$ & 0.53 & 0.23 & 0.44 & 0.47 \\
\hline $\mathrm{Nd}$ & 2.35 & 0.93 & 1.98 & 2.24 \\
\hline $\mathrm{Eu}$ & 1.36 & 0.92 & 0.76 & 0.70 \\
\hline $\mathrm{Sm}$ & 3.73 & 1.89 & 1.98 & 2.10 \\
\hline $\mathrm{Tb}$ & 4.60 & $5 b .82$ & 2.16 & 2.81 \\
\hline $\mathrm{Gd}$ & 19.26 & 20.06 & 10.19 & 11.75 \\
\hline Dy & 36.59 & 64.44 & 13.05 & 20.90 \\
\hline Ho & 7.79 & 16.83 & 2.11 & 3.99 \\
\hline $\mathrm{Er}$ & 24.29 & 59.80 & 4.81 & 10.71 \\
\hline $\mathrm{Tm}$ & 3.86 & 9.91 & 0.63 & 1.39 \\
\hline $\mathrm{Yb}$ & 24.78 & 64.11 & 3.40 & 7.83 \\
\hline $\mathrm{Lu}$ & 3.61 & 9.73 & 0.56 & 1.25 \\
\hline Hf & 1.99 & 0.81 & 4.54 & 2.99 \\
\hline $\mathrm{Ta}$ & $<0.2$ & $<0.2$ & $<0.2$ & $<0.2$ \\
\hline
\end{tabular}

\begin{tabular}{|l|c|c|c|c|}
\hline $\mathrm{U}$ & 0.78 & 0.53 & 0.64 & 0.86 \\
\hline $\mathrm{Li}$ & $<5$ & $<5$ & $<5$ & $<5$ \\
\hline $\mathrm{Cs}$ & $<5$ & $<5$ & $<5$ & $<5$ \\
\hline
\end{tabular}

Y:

Yttrium is found in most rare-earth minerals (Hammond, 1985) it is found in some uranium ores, but is never found in the Earth's crust as a free element (Lenntech contributors, 2008). About $31 \mathrm{ppm}$ of the Earth's crust is yttrium (Simon, 2006), making it the 28th most abundant element, 400 times more common than silver (Emsley, 2001).

High percent of Yttrium is observed in sample 2 (369 ppm), followed by sample 1 (174ppm) and sample 4 (86 ppm) (Figure 1). The $\mathrm{Y}$ is low in sample 3(49ppm).

\section{$\mathrm{Zn:}$}

German chemist Andreas Sigismund Marggraf is credited with discovering pure metallic zinc in 1746 (https://en.wikipedia.org/wiki/Zinc).

The highest concentration of $\mathrm{Zn}$ is observed in sample 3 (175 ppm), followed by sample 2 (168ppm) and sample 4 (145). The low concentrations of $\mathrm{Zn}$ are recorded in sample 1 (132ppm) (Figure 1).

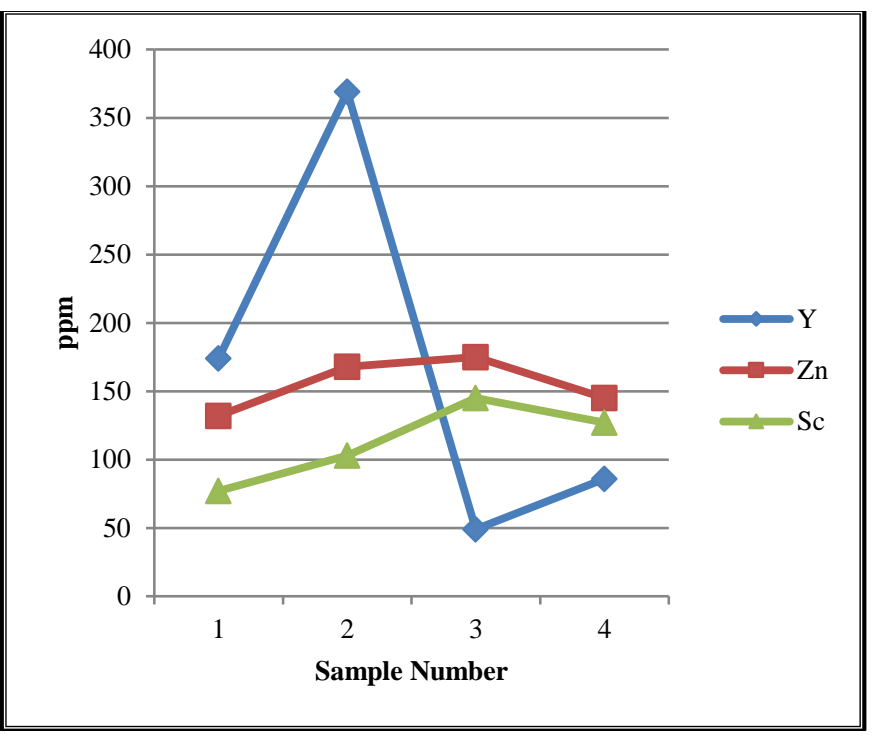

Figure 1. Variation of Trace elements in Almandine Garnet Samples 


\section{Sc:}

Scandium is present in most of the deposits of rareearth and uranium compounds, but it is extracted from these ores in only a few mines worldwide (https://en.wikipedia.org/wiki/Scand- ium). In Earth's crust, scandium is not rare. It is only the 50th most common element on Earth (35th most abundant in the crust), but it is the 23rd most common element in the Sun(David, 2004)

The highest percentage is noticed in sample 3 (145ppm) (Figure 1), followed by sample 4 (127 ppm) and sample 2 (103ppm). 77ppm of sample 1 is low concentration when compared to other samples.

\section{Cr:}

Chromium is the first element in the $3 \mathrm{~d}$ series where the $3 \mathrm{~d}$ electrons start to sink into the inert core. Chromium is extremely hard, and is the third hardest element behind carbon (diamond) and boron (https://en.wikipedia.org/wiki/Chrom- ium).

In our study, chromium concentration is high in sample 2 (86 ppm), followed by sample $4(81 \mathrm{ppm})$. The lower concentrations are noticed in sample 1 and 3 (34 ppm and 37ppm) (Figure 2).

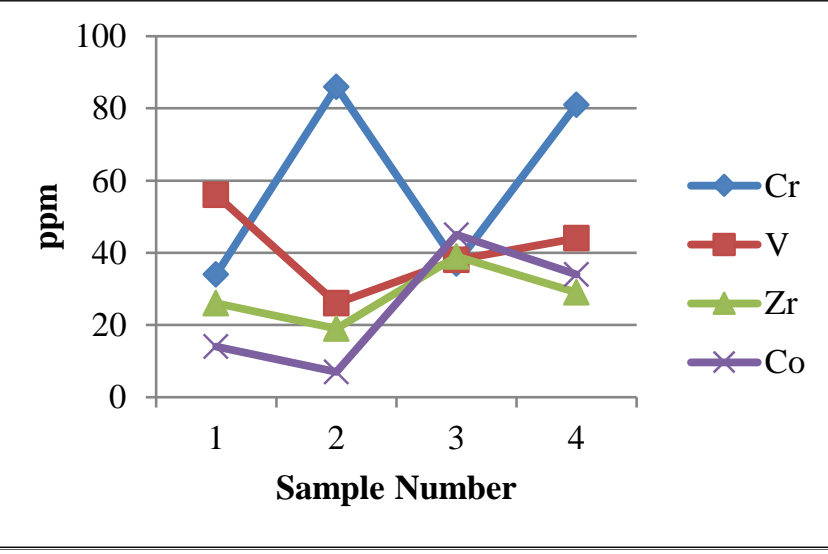

Figure 2. Variation of Trace elements in Almandine Garnet Samples

V:

Vanadium is the 20th most abundant element in the earth's crust(National Cotton Council of America, 1991), metallic vanadium is rare in nature (known as the mineral vanadium, native vanadium) (Ostroomov and Taran, 2015) (Vanadium, 2016)but vanadium compounds occur naturally in about 65 different minerals.

High percent of Vanadium is observed in sample 1 (56 ppm), followed by sample 4 (44ppm) and sample 3 (38 ppm) (Figure 2). The V trace element is low in sample 2 (26ppm).

\section{$\mathrm{Zr}$ :}

Zirconium is relatively abundant in Earth's crust, but not in concentrated deposits, and is characteristically observed in S-type stars. (https://www.britannica. com/science/Zirconium). Zirconium has a concentration of about $130 \mathrm{mg} / \mathrm{kg}$ within the Earth's crust and about $0.026 \mu \mathrm{g} / \mathrm{L}$ in sea water (Peterson and Margaret, 2007). It is not found in nature as a native metal.

The highest percentage is noticed in sample 3 (39 ppm), followed by sample 4 ( $29 \mathrm{ppm}$ ) and sample 1 (26 ppm) (Figure 2). $19 \mathrm{ppm}$ of sample 2 is low concentration when compared to other samples.

\section{Co:}

Cobalt, though widely dispersed, makes up only 0.001 percent of Earth's crust. It is found in small quantities in terrestrial and meteoritic native nickeliron, in the Sun and stellar atmospheres, and in combination with other elements (https://www. britannica.com/science/cobalt-chemical-element).

In our study the high concentration of Co is observed in sample 3 (45 ppm), followed by sample 4 (34 ppm) and sample 1 (14 ppm). The low Co is recorded in sample 2 (7 ppm) (Figure 2).

All other trace elements are present in very low concentrations.

\section{CONCLUSION}

Comparatively, Almandine Garnet has a low price and below middle class peoples can also afford. The study observed that Y (369 to $49 \mathrm{ppm}$ ), Zn (175 to 
132ppm), Sc (145 to $77 \mathrm{ppm}), \mathrm{Cr}$ (86 to $34 \mathrm{ppm}), \mathrm{V}$ (56 to $26 \mathrm{ppm}$ ), $\mathrm{Zr}$ (39 to $19 \mathrm{ppm}$ ) and Co (45 to $7 \mathrm{ppm}$ ) are present in higher concentrations.

\section{REFERENCES}

[1]. David. L.R. (2004) CRC Handbook of Chemistry and Physics. Boca Raton: CRC Press. pp. 4-28.

[2]. Emsley (2001), p. 497.

[3]. Hammond, C.R. (1985) "Yttrium" (PDF). The Elements. Fermi National Accelerator Laboratory. Pp, 4-33. Archived from the original (PDF) on 2008, Retrieved 2008.

[4]. Lenntech contributors. "Yttrium". Lenntech. Retrieved 2008.

[5]. National Cotton Council of America (1991), Proceedings.

[6]. Ostrooumov, M. and Taran, Y. (2015) Discovery of Native Vanadium, a New Mineral from the Colima Volcano, State of Colima (Mexico). Revista de al Sociedad Espanola de Mineralogia 20, pp. 109-110.

[7]. Peterson, J. and Margaret, MacD. (2007) "Zirconium". Radiological and Chemical Fact Sheets to Support Health Risk analyses for Contaminated Areas (PDF). Argonne National Laboratory. Pp. 64-65. Archived from the original (PDF) on 2008 and Retrieved 2008.

[8]. Simon C.A. (2006). "Scandium, Yttrium \& the Lanthanides: Inorganic \& Coordination Chemistry". Encyclopedia of Inorganic Chemistry, doi: 10.1002/0470862106.ia211.

[9]. Vanadium: Vanadium mineral information and data. Mindat.org. Retrieved 2016.

[10]. https://en.wikipedia.org/ wiki/Trace_element

[11]. https://en.wikipedia.org/wiki/Garnet

[12]. https://www.britannica.com/science/garnet

[13]. https://www.wikigempedia.com/garnet.html

[14]. https://en.wikipedia.org/wiki/Zinc
[15]. https://en.wikipedia.org/wiki/Scandium [16]. https://en.wikipedia.org/wiki/Chromium [17]. https://www.britannica.com/science/zirconium [18]. https://www.britannica.com/science/cobaltchemical-element

\section{Cite this article as :}

Nazia Sultana, "Trace Elements in Almandine Garnet, Vemireddipalle Area, Krishna District, Andhra Pradesh, India", International Journal of Scientific Research in Science and Technology (IJSRST), Online ISSN : 2395-602X, Print ISSN : 2395-6011, Volume 6 Issue 4, pp. 184-187, July-August 2019. Available at doi : $\quad$ https://doi.org/10.32628/IJSRST196438 Journal URL : http://ijsrst.com/IJSRST196438 